\title{
Measuring soil evaporation from a cropped land in the semi-arid Makanya catchment, northern
} Tanzania: methods and challenges

\author{
Authors: K. A. Nyabwisho ${ }^{a^{*}, b}$, J. Diels ${ }^{b}$, F.C. Kahimba ${ }^{c}$, A. van Griensven ${ }^{d}$ \\ a Department of Water Resources and Irrigation, Water Institute (WI), Dar es Salaam, Tanzania \\ ${ }^{\mathrm{b}}$ Soil and Water Division, Department of Earth and Environmental Sciences, KU Leuven, Belgium \\ c Department of Engineering Sciences and Technology, Sokoine University of Agriculture (SUA), \\ Morogoro, Tanzania \\ ${ }^{\mathrm{d}}$ Department of Hydrology and Hydraulic Engineering, Vrije Universiteit Brussel, Belgium
}

\begin{abstract}
Estimating soil water loss from cropped land is vital for sustainable management of water resources in semi-arid and hot regions. Soil evaporation $\left(E_{\mathrm{s}}\right)$ is an important process in these regions but hard to quantify. The study aimed at quantifying $\mathrm{E}_{\mathrm{s}}$ in maize field under three treatments using microlysimeters (MLs). It also aims to identify sources of challenges in the method. The treatments were; flat cultivation with mulching (FCM), without mulches (FC) and double digging (DD, manual tillage practice), were replicated trice. In each plot, two micro-lysimeters were installed, one containing soil samples to measure soil evaporation and an empty one to measure throughfall ( $\mathrm{Tr})$ under the maize canopy. The 24-hr soil samples weight change and throughfall records were used to estimate soil evaporation for each plot. The estimated mean daily soil evaporation was $3.4 \mathrm{~mm} /$ day in FC, 2.1 $\mathrm{mm} /$ day in FCM and $3.0 \mathrm{~mm} /$ day for DD. There was a challenge in the method during the rainfall period which lead to both negative and high $E_{s}$ values during rainfall period. Less throughfall from empty MLs than in soil containing MLs caused the negative $E_{s}$ and the opposite was true for higher $E_{s}$ during rainy period. We urge the method to be improved by measuring throughfall simultaneously with soil weight changes immediately after rainfall events and minimize random errors by using many MLs. To have more results on reducing water losses while increasing available water for crop growth in this water scarce environment, we suggest FCM to be combined with DD treatment.
\end{abstract}

Key words:

Double-digging; Maize; Mulching; Micro-lysimeter; Soil evaporation; Semi-arid 


\section{Introduction}

Food insecurity is a global challenge. This challenge is primarily enlarged by the ever high population growth of the world (especially in developing countries with an average growth rate of more than 3\%), (World Bank, 2002; WHO, 2000). Due to this, the world population is projected to double by the year 2050 (UN Population Division, 2012). On other hand, water scarcity due to low and erratic rains in the semi-arid region, worsens the situation. Makanya catchment, Tanzania being a semi-arid area with water scarcity and high population also faces food insecurity challenge.

Farmers in this catchment are smallholders with low income and have no reliable irrigation schemes, therefore rely on rainfed crop production system. The catchment receives insufficient seasonal rainfall to meet the crop water requirement of maize which is a staple food in the area. The maize crop water requirement in the catchment is $508 \mathrm{~mm} / \mathrm{season}$ (Makurira et al., 2011; Mutiro et al., 2006). The little rainfall received in the catchment area has not been recharging the underground reservoirs of the catchment (Makurira et al., 2007), rather is being lost through evaporation. The part of the evaporation is unproductive (soil evaporation), which is not often measured and it is therefore necessary to direct more water to the plant available zones and make it a productive evaporation (transpiration).

The potential evaporation in the area is $10 \mathrm{~mm} /$ day (Mul, 2009). The better understanding on evaporation (its measurement method from the field) and different ways to reduce it is therefore vital in the region as evaporation is unproductive water loss which contributes to crop yield reduction in this drought prone region.

Soil evaporation $\left(E_{s}\right)$ is a hydro-physical process that removes water from soil to the atmosphere (Nyenzi et al., 1981) making it unavailable for plants. It is a major component of terrestrial hydrological cycles (Wallace, 1995) and agricultural systems (Daamen et al., 1993; Daamen et al., 1995; Jackson and Wallace, 1999). $\mathrm{E}_{\mathrm{s}}$ as a component of evapotranspiration (ET), accounts for 40\% $70 \%$ of water loss from cropped land in semi-arid areas (Balwinder-Singh et al., 2011; Allen, 1990). Therefore soil evaporation is an important component of the water budget in the tropics, in particular in semi-arid conditions, although its measurement is not easy especially in low economy countries.

Evaporation from drying soil proceeds in two stages (Ritchie, 1972): Stage 1 or the constant rate stage occurs when the soil is wet and $E_{s}$ is determined by the evaporative demand, and the process is thus considered energy-limited. In this stage, soil evaporation is limited by available heat energy near the surface and the vapour pressure gradients between the soil and the atmosphere (Han et al., 2017). Stage 2 or the falling rate stage occurs when the top soil becomes too dry to transport water to the evaporating surface. The transport of the moisture from deeper soil to the surface limits the process and is therefore governed by the hydraulic properties of the soil (Brutsaert, 2014). Stage 1 has high 
and constant $\mathrm{E}_{\mathrm{s}}$ whereas stage 2 has low and gradually dropping $\mathrm{E}_{\mathrm{s}}$ rates (Han et al., 2017; Or and Shokri, 2013).

$E_{s}$ from cropped land is influenced by agricultural management practices on soil surface such as mulching and tillage and affected by shading from the canopy which is close related to leaf area index (LAI). While both shading and mulching are known to reduce the $\mathrm{E}_{\mathrm{s}}$ rate (Eberbach and Pala, 2005; Jackson and Wallace, 1999; Li and Dyck, 2018; Li et al., 2013; Shawcroft and Gardner, 1983), tillaging also seems to reduce it by conserving moisture in deep depths of the profile (Campbell and Akhtar, 1989; Schwartz et al., 2010; Zhang et al., 2011; Zribi et al., 2015).

From a crop production perspective, soil evaporation in a water-scarce area is an unproductive loss, and reducing it makes more water available for crop production. Therefore, a good and reliable method for the direct Es estimation is required.

Water loss (in form of $E_{s}$ ) from cropped lands is estimated either through a direct field measurement approach (Allen, 1990; Boast and Robertson, 1982; Daamen et al., 1993; Wythers et al., 1999) or simulated by hydrological models (Aydin, 2008; Harp, et al., 2007). Direct field measurements involves in situ measuring of the incoming and outgoing water fluxes, thus closing the water balance in the soil profile. Another approach to direct estimating soil evaporation from the field is by isotope method as in Sutanto et al. (2012). Hydrological simulations require readily measurable parameters (e.g. weather, soil and crop) (Allen, 1990; Boesten and Stroosnijder, 1986) and models (e.g the FAO P-M) consider crops to be grown under optimum conditions. Soil evaporation can also be estimated at field scale through algorithms which works through energy balance and heat transfer methods. For bare fields, the Eddy covariance method as reported in Gebler et al. (2015) and the Bowen ratio method (Mastrorilli et al., 1998) can be used to measure soil evaporation.

The common direct field measurement method for soil evaporation is the use of micro-lysimeters (Lascano and Van Bavel, 1986); Daamen et al., 1993). Micro-lysimeters (MLs) are small soil cores installed in bare fields or under crop canopies (installed with the rim slightly above the ground level) and checked daily to detect the change in soil water storage. MLs are closed at the base to ensure no water escapes from the bottom of the MLs and percolates deep into the soil profile. The $\mathrm{E}_{\mathrm{S}}$ can either be estimated by measuring moisture content of the soil in MLs as done in Wythers et al. (1999) or by using ML weight differences taken on two successive days as detailed in Boast and Robertson (1982). Different soil surface management practices that affect soil evaporation can be studied when using the MLs method.

The validity of the ML method is achieved when the estimated $E_{s}$ of the soil sample is the same as that of the comparable soil in field (Boast and Robertson, 1982). Several studies urge that whenever the ML method is used regardless of the dimensions, the soil core should maximally be used for 2 days 
when there is no rainfall (Allen, 1990; Boast and Robertson, 1982; Daamen et al., 1993). Others suggest longer lifetimes for the soil cores of 6-7 days (Matthias et al., 1986; Daamen et al., 1993) and 8-10 days (Evett et al.,1995; Walker, 1983). Since a new core is taken for every measurement cycle, the soil core has always undergone the same field management operation as the surrounding soil. The method is reported to perform well in periods without rainfall but to have difficulties during rainy periods (Allen, 1990; Jackson and Wallace, 1999; Plauborg, 1995). Although the rain that falls into MLs affects $E_{s}$ estimation and leads into inaccuracies of the method, little is reported on how it is collected and integrated into the $\mathrm{E}_{\mathrm{s}}$ estimation process from the field measurements. Other possible cause of errors in the ML method could be the use of ML casing materials that have thermal characteristics different from that of the soil and the use of ML designs that lead to a water loss that cannot be accounted for.

This study aimed at measuring water loss (through soil evaporation) from a rainfed maize field with different management practices in the Makanya catchment, Tanzania. Specific objectives were to use MLs to estimate $E_{\mathrm{s}}$ directly from in situ field measurements and to identify possible sources of uncertainties and challenges in the methods.

\section{Materials and methods \\ 2.1 Experimental site description}

The experiment was carried out in Bangalala village, the mid-land of the Makanya catchment, Same District, Northern Tanzania. The site is located at $4^{\circ} 23^{\prime} \mathrm{S}$ and $37^{\circ} 85^{\prime} \mathrm{E}$, at an altitude of $910 \mathrm{~m}$ above sea level. The climate in the area is semi-arid with two rainy seasons: one with short rainfall period, known as Vuli, during October-December and a long rainfall season termed Masika, from March to June. The climate in the area is characterized by a high year-to-year variation of seasonal and annual rainfall variations and frequent occurrence of dry spells (Enfors \& Gordon, 2007; Mul et al., 2009). The seasonal rainfall in the Vuli season is more variable (from year to year) than seasonal rainfall in the Masika season thus making the Vuli rainfall less predictable (Enfors \& Gordon, 2007). The period between the two seasons, January and February is hot and dry. Annual rainfall in the area ranges between 500 and $600 \mathrm{~mm} /$ year (Pachpute et al., 2009) and is always lower than reference evapotranspiration thus making the area semi-arid with a characteristic of crop production failures due to water scarcity. Figure 1 shows the daily $\mathrm{ET}_{\mathrm{o}}$ and rainfall for Bangalala met station for the year 2017/2018. $\mathrm{ET}_{\mathrm{o}}$ in highest daily $\mathrm{ET}_{\mathrm{o}}$ during dry month of February and it decreases during the rainy season. The soil is red and deep $(>200 \mathrm{~cm})$, with a sandy clay texture from the surface to $90 \mathrm{~cm}$ depth and sandy clay loam in deeper horizons (Table 1). Small scale farming of maize crop as a staple food 
is the main activity in the area. The maize crop is grown in both seasons. In this study, the experiment was carried out during Masika under rainfed conditions.

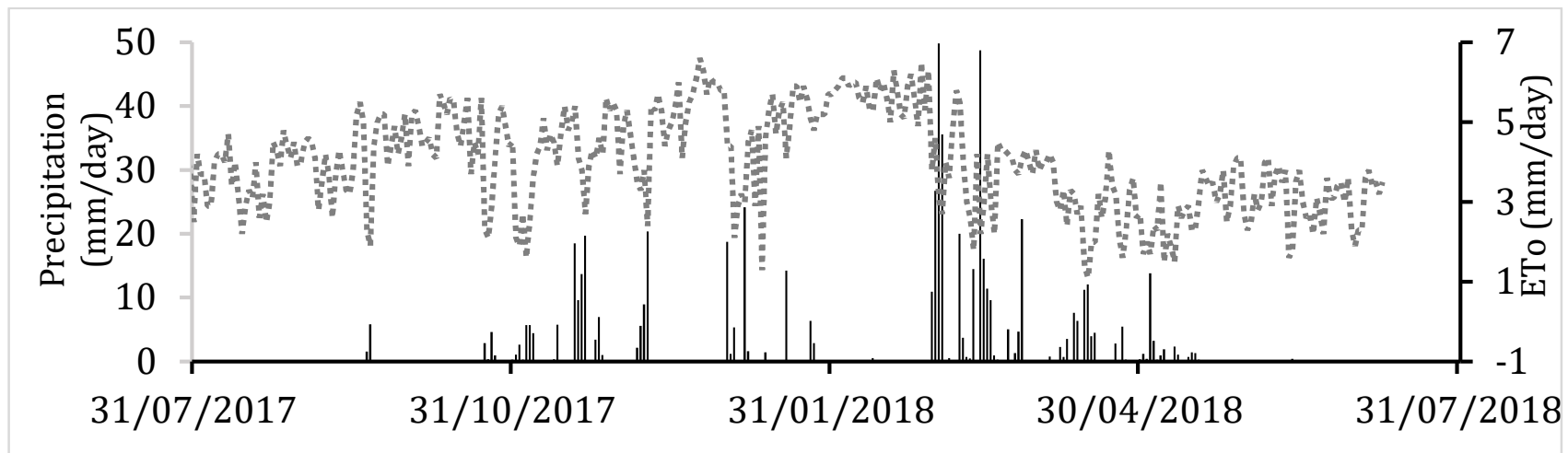

Figure 1. The daily ET, shown as dots on the right hand Y-axis and daily precipitation shown as a bar graph with the left hand Y-axis data for Bangalala village, in Makanya catchment, Tanzania.

Table 1.The hydrophysical soil properties measured in the experimental field.

\begin{tabular}{llllllllll}
\hline Texture & $\begin{array}{l}\text { Depth } \\
(\mathrm{cm})\end{array}$ & $\begin{array}{l}\text { Clay } \\
\%\end{array}$ & $\begin{array}{l}\text { Sand } \\
\%\end{array}$ & $\begin{array}{l}* \mathrm{OC} \\
\%\end{array}$ & $\begin{array}{l}\theta_{\mathrm{PWP}} \\
\left(\mathrm{cm}^{3} / \mathrm{c}\right. \\
\left.\mathrm{m}^{3}\right)\end{array}$ & $\begin{array}{l}\theta_{\mathrm{FC}} \\
\left(\mathrm{cm}^{3} / \mathrm{c}\right. \\
\left.\mathrm{m}^{3}\right)\end{array}$ & $\begin{array}{l}\theta_{\mathrm{s}} \\
\left(\mathrm{cm}^{3} / \mathrm{c}\right. \\
\left.\mathrm{m}^{3}\right)\end{array}$ & $\begin{array}{l}\rho_{b} \\
(\mathrm{~g} / \mathrm{c} \\
\left.\mathrm{m}^{3}\right)\end{array}$ & $\begin{array}{l}\mathrm{pH} \\
1: 2.5\end{array}$ \\
\hline \multirow{3}{*}{ Sandy clay } & $0-30$ & 41.1 & 49.2 & 0.95 & 0.11 & 0.23 & 0.45 & 1.44 & 7.85 \\
& $30-60$ & 40.1 & 55.2 & 0.71 & 0.13 & 0.22 & 0.43 & 1.35 & 7.80 \\
& $60-90$ & 40.1 & 52.2 & 0.42 & 0.16 & 0.24 & 0.44 & 1.34 & 7.65 \\
Sandy clay loam & $90-120$ & 32.1 & 59.2 & 0.35 & 0.15 & 0.27 & 0.45 & 1.37 & 7.48 \\
\hline
\end{tabular}

\subsection{Experimental treatments design}

A field trial was carried out during Masika season of 2018 under rainfed conditions with three field management practices, namely flat cultivation (FC), flat cultivation with mulching (FCM) and double digging (DD). FC means land preparation was done by digging with a normal hand hoe on a shallow depth, (say 0-6 cm from the surface) to remove any unwanted plants and without turning the soil as done by farmers, and therefore served as a control. FCM was done as in FC but by spreading $11.4 \mathrm{t} /$ ha maize stovers over about $80 \%$ of the ground on both sides of the crop rows, leaving the planting line (about $20 \%$ of the crop row area) uncovered. DD was first done as in FC but additionally involved making a planting row by digging twice deep (to about $50 \mathrm{~cm}$ from the surface) by using a small (10 cm wide and $25 \mathrm{~cm}$ length) hand hoe to loosen any compacted soil layer for easy incorporation of organic manure and to enhance easy redistribution of water deeper into the soil profile. The manure was first added to the planting hole, seeds were sown and covered with a layer of soil. The hypothesis on the DD treatment was that it would improve redistribution and deeper water infiltration similar to deep tillage effect as reported by Campbell and Akhtar (1989), thus increasing 
its availability at the rootzone as also discussed in Schneider et al. (2017). As a result, evaporation is reduced at the soil surface as compared to a minimum-till practice (FC) with water redistribution ability, a similar findings on the effect of a tillage on $E_{s}$ is reported in Sillon et al. (2003). But a risk is that, with a prolonged long period of heavy rains the more intensely tilled soil of the DD treatment may become compacted and its infiltration capacity could be reduced. Treatments were replicated three times and arranged in a randomized complete block design. The field plot size was $10 \mathrm{~m}$ by $7 \mathrm{~m}$, and a spacing of $1.5 \mathrm{~m}$ was left between the blocks and $1 \mathrm{~m}$ between plots within a block as pathways in the experimental plot (Figure 2).

Rainfall started in March and the maize seed was sown on $15^{\text {th }}$ March 2018 when soil moisture was adequate. The initial soil moisture content (SMC, 0-30 cm depth) at planting was $0.26 \mathrm{~cm}^{3} / \mathrm{cm}^{3}$. The maize variety was Seedco $513^{1}$ which is known to be early maturing, high yielding, and drought tolerant in the area. Two seeds were sown at $0.35 \mathrm{~m}$ between stands (thinned to 1 plant per stand) and $0.75 \mathrm{~m}$ between the rows, making a plant density of 38,095 plants per hectare. The effect of each agricultural management practices on reducing unproductive losses of soil water was subsequently evaluated.

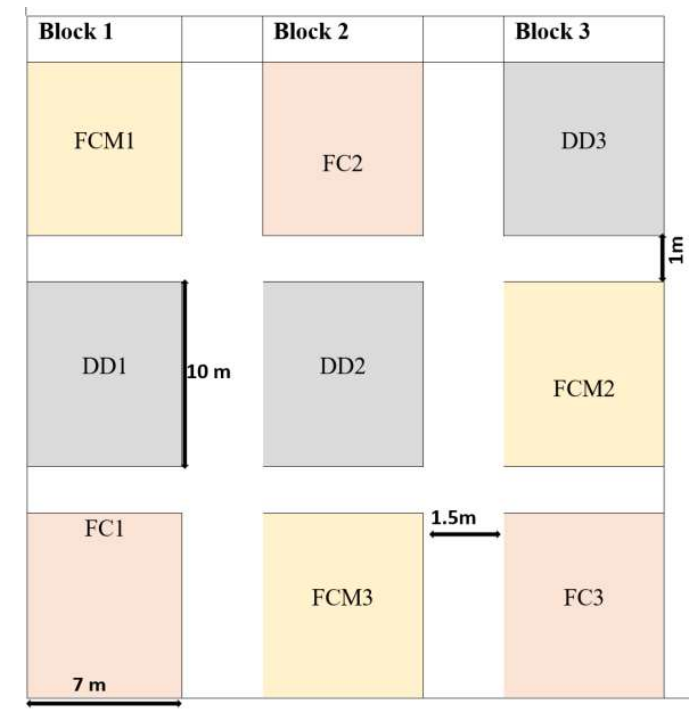

Figure 2. Experimental layout: treatments FCM, DD and FC replicated three times in a randomized complete block design.

\subsection{Micro-lysimeter method for field estimation of $\mathrm{E}_{\mathrm{s}}$}

A micro-lysimeter method was used to estimate soil evaporation from the experimental plots as detailed in Boast and Robertson (1982), and shown in Figure 3. The micro-lysimeters were constructed from PVC pipes of $8.9 \mathrm{~cm}$ diameter and $15 \mathrm{~cm}$ height. The materials and design of the microlysimeters

\footnotetext{
${ }^{1}$ http://www.seedcogroup.com
} 
as explained in Daamen et al. (1993) need to reflect the characteristics of the soil column in the field. A set of 2 MLs placed at a random distance (each at about $30-35 \mathrm{~cm}$ from the row) and about $50 \mathrm{~cm}$ apart were used in each plot; one was filled with an undisturbed soil sample (soil core) for detection of moisture loss by weighing it on a daily basis. The second micro-lysimeter in each plot was an empty one that was closed at the bottom with a plastic cup and tightened by adhesive tape at the bottom for collecting throughfall (from rain) and thus enable quantification of rainfall that enters into the nearby MLs with soil. The two lysimeters had a casing envelope PVC pipes (11 cm diameter) which remained in the soil throughout the season. The undisturbed soil samples were taken manually by pushing the ML vertically into the soil until a small (about $1 \mathrm{~cm}$ ) top side of the ML remained unfilled, and it was removed gently to avoid structure alteration. The excess soil at the base of the ML was trimmed and the bottom sealed with a plastic sheet and rubber band to make it watertight similarly as the empty MLs. The MLs were then weighed and placed back into the casing. The top side of the ML and casing were extended 1 to $2 \mathrm{~cm}$ above the soil surface to prevent run-on.

In the beginning of the season ( $23^{\text {rd }}$ March to $23^{\text {rd }}$ April), the soil cores were retained up to four days, as this was a wet period and soil moisture stayed long in the ML before drying took place. For the rest of the season ( $24^{\text {th }}$ April to $30^{\text {th }}$ June) the soil cores were resampled after two days to avoid any divergence from the surrounding soil in the dryer period. In very few cases, the sample was replaced after one day. A portable digital scale with a precision of $0.1 \mathrm{~g}(\approx 0.016 \mathrm{~mm}$ of water) was used to check for weight changes in the soil samples in the MLs daily at around 9:00 am. Before weighing the soil samples the weighing scale was checked for its accuracy by first weighing a calibration weight. The checking was done by placing the weighing scale on a flat surface (ground or flat wood placed on the ground) and a calibration weight was placed at the centre of the scale to verify that its correct weight was recorded. It was therefore considered precise and ready to weigh the samples. The weight change $\left(\Delta m M L_{t}\right.$ in grams) of the ML containing soil over 24 hours were detected by taking the difference between the previous and the next weights. Throughfall from empty MLs in all plots was measured by first weighing the MLs with the collected water, subtracting the weight of empty ML and converting the weights into millimetres of water by considering the area of ML and the density of water. The weight change and throughfall rain were used to calculate $\mathrm{E}_{\mathrm{s}}$ as detailed under section 2.6. 


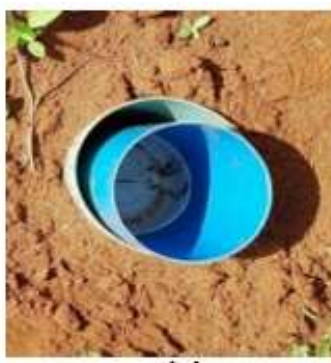

(a)

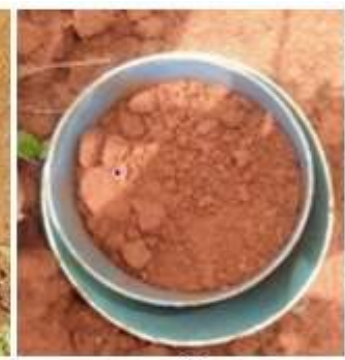

(b)

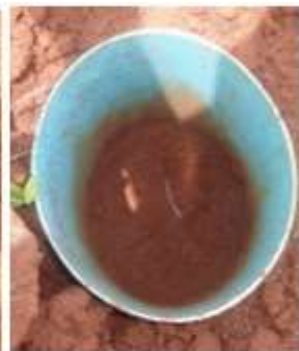

(c)

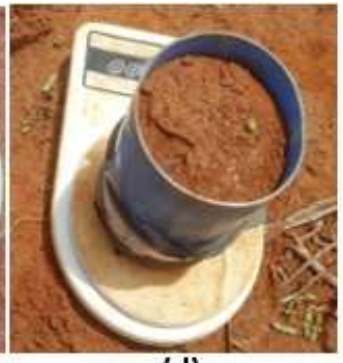

(d)

Figure 3. Micro-lysimeter (ML) setup and procedure for measuring soil evaporation: (a) empty ML for rainfall recording (b) ML with (undisturbed) soil core (c) ML envelope and (d) weighing ML with soil using a digital scale.

\subsection{Weather and soil data}

A standard manual rain gauge installed in the middle of the experimental field was used to record daily rainfall for the entire season. However, the rainfall was also as recorded with a weather station located at about 585 meters from the experimental field. Daily records for solar radiation, maximum and minimum air temperature, mean relative humidity and wind speed were obtained from another automatic weather station (1.5 $\mathrm{km}$ from the experimental field).These data were used to estimate the reference evapotranspiration (ETo $)$ using the FAO Penman-Monteith method (Allen et al., 1998).

Soil samples were collected every 2 or 3 weeks using gouge augers to monitor soil moisture content $(0-30,30-60,60-90,90-120 \mathrm{~cm}$ depths $)$. This was done by sampling each plot at three randomly chosen positions to a depth of $1.2 \mathrm{~m}$, and mixing the sampled soil per plot and depth interval. Soil cores $\left(100 \mathrm{~cm}^{3}\right)$ were taken once in each depth interval to determine bulk density, which was used to convert measured gravimetric soil water content $(\mathrm{g} / \mathrm{g})$ into volumetric water content $\left(\mathrm{cm}^{3} / \mathrm{cm}^{3}\right)$.

\subsection{Canopy cover (CC) for the estimation of potential $\mathrm{E}_{\mathrm{s}}$.}

Green canopy cover data was collected every three weeks from crop germination to maturity using the Canopeo application (Patrignani and Ochsner, 2015). Canopeo is a mobile phone application which is used to calculate fractional green canopy cover of the crop by taking overhead pictures with the phone camera. The images are taken at $60-100 \mathrm{~cm}$ above the crops while the camera is positioned parallel to the ground (https://www.greenappsandweb.com). The application presents the original image and the processed black and white image where the detected green canopy cover is rendered as white pixels (Figure 4). The CC (\%) were used together with $\mathrm{ET}_{\mathrm{o}}$ to estimate potential soil evaporation as in equation 1 , for the comparison with the actual soil evaporation from the experimental field.

$$
E_{\text {pot }}=E T o * \frac{(100-C)}{100}
$$

Equation 1.

where $\mathrm{CC}(\%)$ is the green canopy cover, $\mathrm{E}_{\text {pot }}(\mathrm{mm})$ is the potential soil evaporation, $\mathrm{ET}_{\mathrm{o}}(\mathrm{mm})$ is the reference evapotranspiration. 

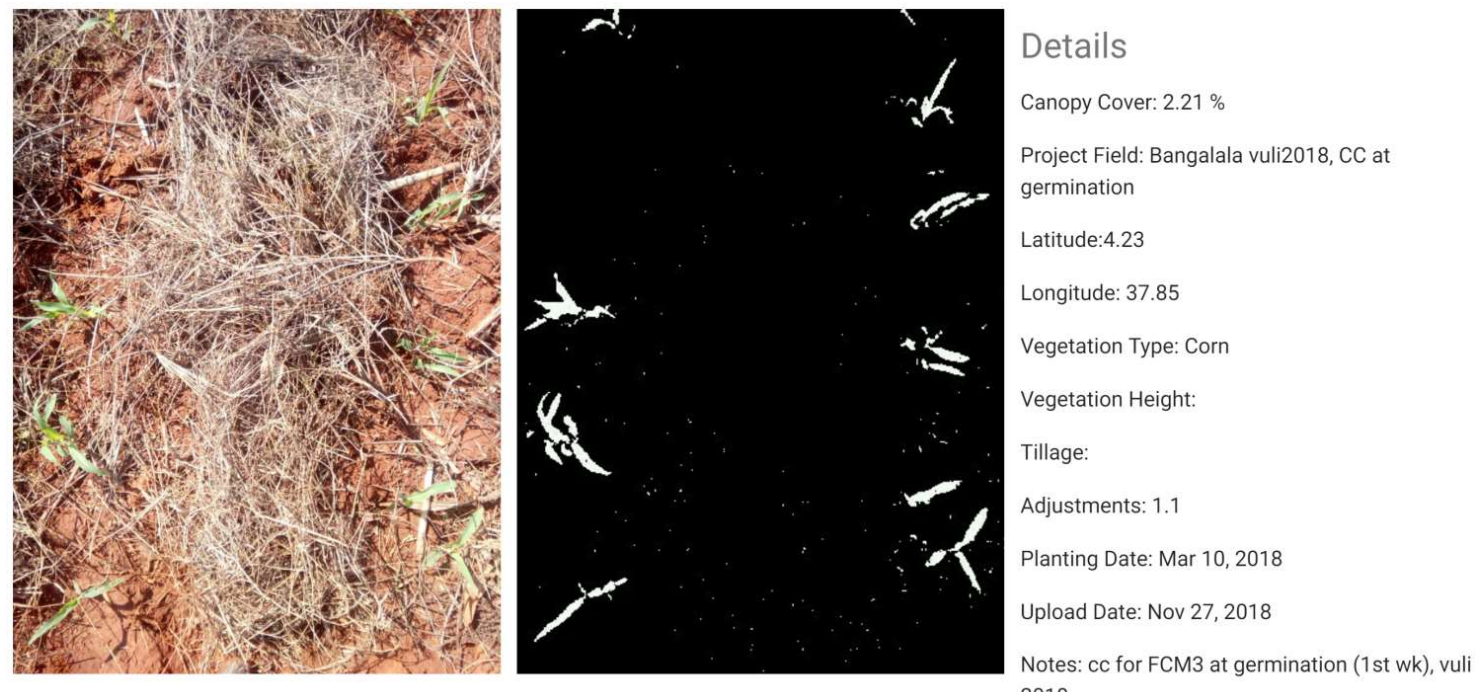
2018

Figure 4. An overhead picture of maize at seedling stage at Bangalala field experiment in the Masika season of 2018 before (left) and after (right) analysis for canopy cover.

\section{$2.6 \mathrm{E}_{\mathrm{s}}$ calculation procedures}

The weight change of the soil contained in MLs and throughfall (from rain) recorded using empty MLs were used to determine $E_{s}$. The differences between the weight at the beginning of 1-day time step $\left(m_{M L t 1}\right)$ and the weight at the end of the time step $\left(m_{M L_{t 2}}\right)$ (obtained by weighing the ML each morning) was used to obtain the $\mathrm{E}_{\mathrm{s}}$ for the time step as follows:

$E s=\left(\frac{10}{\rho_{w}} \times \frac{m_{M L t 1}-m_{M L t 2}}{A_{M L} \times \Delta t}\right)+\mathrm{T} r$

Equation 2.

where $E_{\mathrm{s}}-$ is the soil evaporation $(\mathrm{mm} /$ day $), \rho_{\mathrm{w}^{-}}$- density of water $\left(1 \mathrm{~g} / \mathrm{cm}^{3}\right) ; \mathrm{r}$-throughfall rainfall $\left(\mathrm{mm} /\right.$ day) per plot collected in empty $\mathrm{ML} ; \mathrm{A}_{\mathrm{ML}}$ - area $\left(\mathrm{cm}^{2}\right)$ of $\mathrm{ML} ; \mathrm{m}_{\mathrm{ML}_{\mathrm{t} 1}}$ - weight $(\mathrm{g})$ of $\mathrm{ML}$ at start of time step; $\mathrm{m}_{\mathrm{ML} 22}$ - weight ( $\mathrm{g}$ ) of $\mathrm{ML}$ at end of time step; $\Delta \mathrm{t}$ length of time step (1 day).

2.7 Statistical methods

JMP

The

3. Results and discussion

3.1 Weather data for the crop growing season

The rainfall started early March but the recording in the experimental field was delayed until $15^{\text {th }}$ March 2018 due to delayed planting. The total seasonal rainfall recorded from planting to the end of the season was $252 \mathrm{~mm}$. Most rainfall (222 mm) was received in March and April (Figure 1) when the crop was at vegetative stage and the rest in May when crops were at flowering stage. The last rainfall event occurred in June, which sustained the crop to maturity given that the variety had a growth cycle of 3.5 months. Solar radiation was high during the dry and hot period of January -February until mid- 
March, with a maximum of $289 \mathrm{~W} / \mathrm{m}^{2} /$ day in March. It decreased in April and May and started to increase in June. The maximum and minimum air temperature $\left({ }^{\circ} \mathrm{C}\right)$ followed the same trend as the solar radiation. The daily reference evapotranspiration $\left(\mathrm{ET}_{\mathrm{o}}, \mathrm{mm} /\right.$ day $)$ followed the same trend. The daily $\mathrm{ET}_{\mathrm{o}}$ was high during March, at the beginning of the rainy season when $\mathrm{RH}$ was low $77.1 \%$ and solar radiation high, (Figure 5), and decreased with the latter. Relative humidity increased with the increase in rainfall, and the maximum (95\%) was recorded in May.

There were variations in the mean throughfalls among the treatments at different times of crop growth. A significant difference on the throughfall is observed only on three out of the 20 days with rainfall. The first and second significant differences was observed between DD and FC treatments which occurred during the $2^{\text {nd }}$ and $4^{\text {th }}$ weeks of the crop respectively. The last significant difference was observed between FCM and FC treatments during the $7^{\text {th }}$ week of the crop when the ground was mostly covered by canopy. There was no significant difference between DD and FCM treatments for the entire season. The differences in the throughfalls among the treatments during partial and ful canopy cover may be due to variations in $\mathrm{CC}$ which was also observed during the season (see also section 3.3). However, the throughfall difference between DD and FC treatments which was recorded at 2 week crop age when the ground was not covered or with small cover ( $\mathrm{CC}$ of $<6 \%$ ) indicates less $\mathrm{CC}$ effect to it. Due to the heterogeneity of the canopy (reported in section 3.3) and the effects of a few maize leaves randomly positioned above a ML on the throughfall collected in the ML, recorded throughfall in the empty MLs is variable (the coefficient of variation were $144 \%, 130 \%$ and $137 \%$ for DD, FC and FCM are respectively). Therefore, the evaporative demand (high solar radiation and air temperature) and rainfall governed the $\mathrm{E}_{\mathrm{s}}$ levels and trend during the season (Figure 5). The $\mathrm{E}_{\mathrm{s}}$ was low in the beginning of the season (when radiation was high but moisture content in the soil low) and became high in the middle of the season (from mid-April) when there the soil was wet due to heavy rains which fell in March and April.

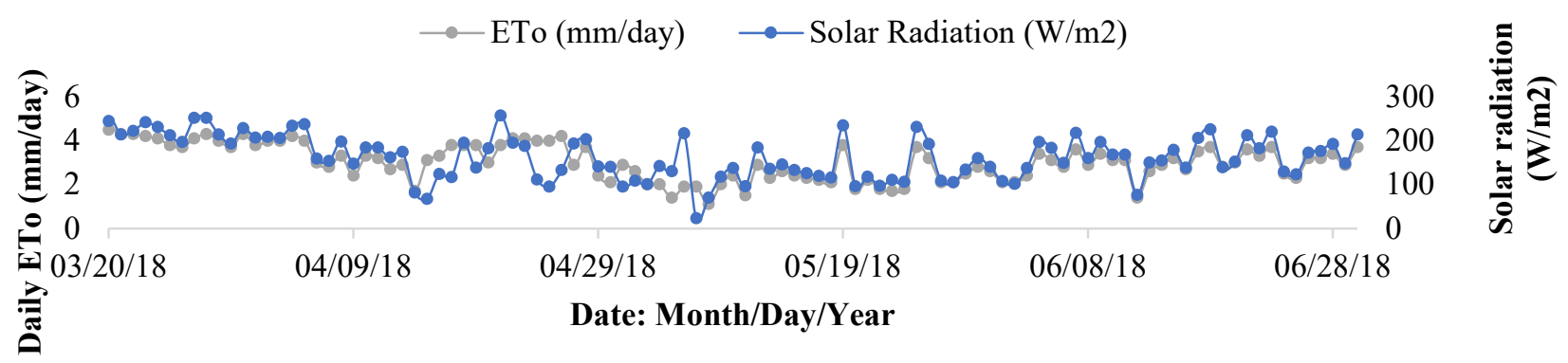

Figure 5. Bangalala daily ETo $\left(\mathrm{mm} /\right.$ day) and solar radiation $\left(\mathrm{W} / \mathrm{m}^{2}\right)$, both recorded during Masika season, 2018. 


\subsection{Effect of agricultural management practices on soil moisture content}

The initial SMC (0-30 cm depth) at planting, which was measured gravimetrically after the first rainfall event, was $0.26 \mathrm{~cm}^{3} / \mathrm{cm}^{3}$. The SMC followed the rainfall trend, the highest levels among treatments were recorded during the rainfall period of the season (Figure 6). There was a significant difference $(p=0.007)$ in SMC between FCM and FC, and between FCM and DD throughout the season. FC had lower SMC compared to other treatments, but close to that of DD throughout the season (Figure 6). Therefore, the difference between the FC and DD treatments was not statistically significant. The average seasonal SMC in the $0-30 \mathrm{~cm}$ layer was $0.22 \mathrm{~cm}^{3} / \mathrm{cm}^{3}$ in FCM, $0.19 \mathrm{~cm}^{3} / \mathrm{cm}^{3}$ in $\mathrm{DD}, 0.18 \mathrm{~cm}^{3} / \mathrm{cm}^{3}$ in FC plots. The slightly higher SMC which is observed in DD as compared to FC plots could be due to rainfall water redistribution in the DD treatment. DD plots had an average SMC of $0.25 \mathrm{~cm}^{3} / \mathrm{cm}^{3}$ and $\mathrm{FC}$ had $0.22 \mathrm{~cm}^{3} / \mathrm{cm}^{3}$ during the rainy and wet period but the two recorded almost the same SMC at the end of the season. The DD plots experienced drastic moisture decrease during dry spells compared to the rest of the treatments in the season. The low SMC in DD and FC is likely due to the high soil evaporation from these treatments relative to FCM that lead to decreased soil water content in their respective plots.

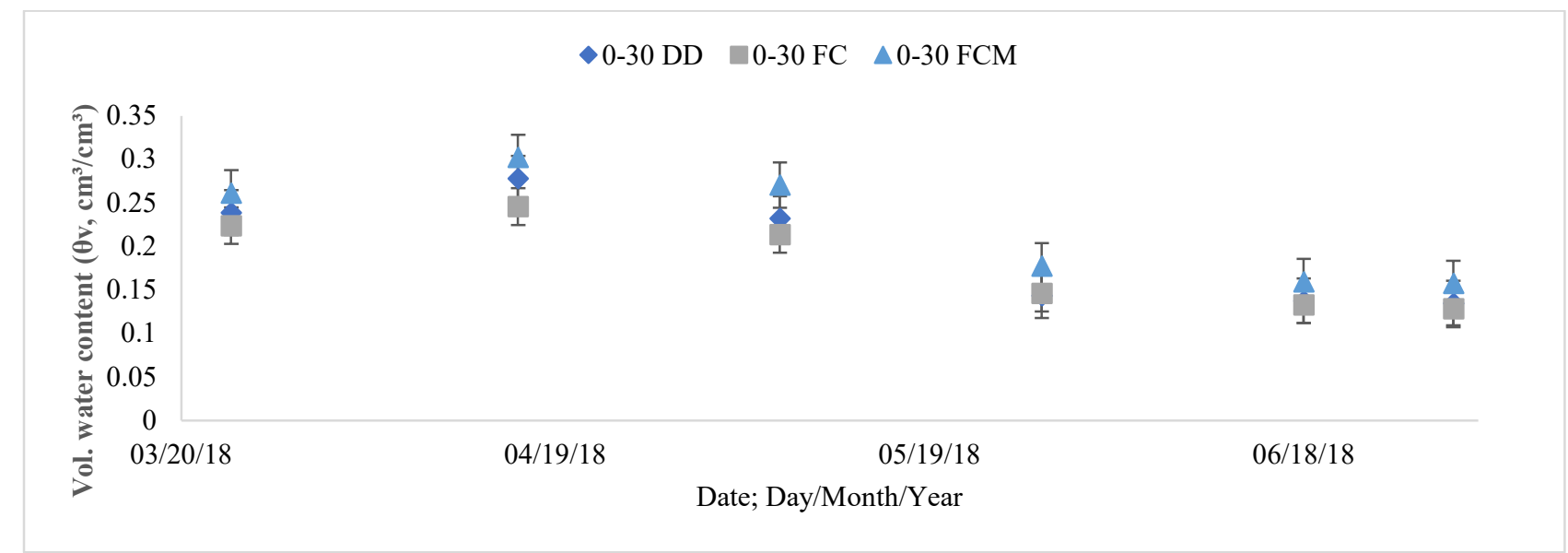

Figure 6. Volumetric water content per treatment (0 -30 cm of the soil profile) during the Masika season of 2018 (error bars are $+/$ - standard errors of the means)

\subsection{Canopy cover (CC) and the estimation of $\mathrm{E}_{\mathrm{s}}$}

$\mathrm{CC}$ variation between treatments was not significant. Both potential and actual soil evaporation followed the same trend although $E_{\text {pot }}$ was much higher than the actual $E_{s}$ at the beginning (Figure 7).This could be due to low SMC during the same period as compared to the time when the SMC was also high. In the middle of the season when the area received heavy rains, there was noise in the $\mathrm{E}_{\mathrm{s}}$ data whereby actual $E_{s}$ often exceeded the potential $E_{s}$ (Figure 7). Although the $\mathrm{CC}$ varied among treatments and one would expect this to have a significant effect on $\mathrm{E}_{\mathrm{s}}$ among the treatments, this was 
not statistically significant at 5\% level. Results suggested that the observed $\mathrm{E}_{\mathrm{s}}$ differences among the treatments in the season were not mainly caused by $\mathrm{CC}$, but due to the effect of management practices on the soil surface (mulching and tillage by DD). This is supported by the fact that the variation was observed even when the crops were still young with no or low CC (Figure 8).

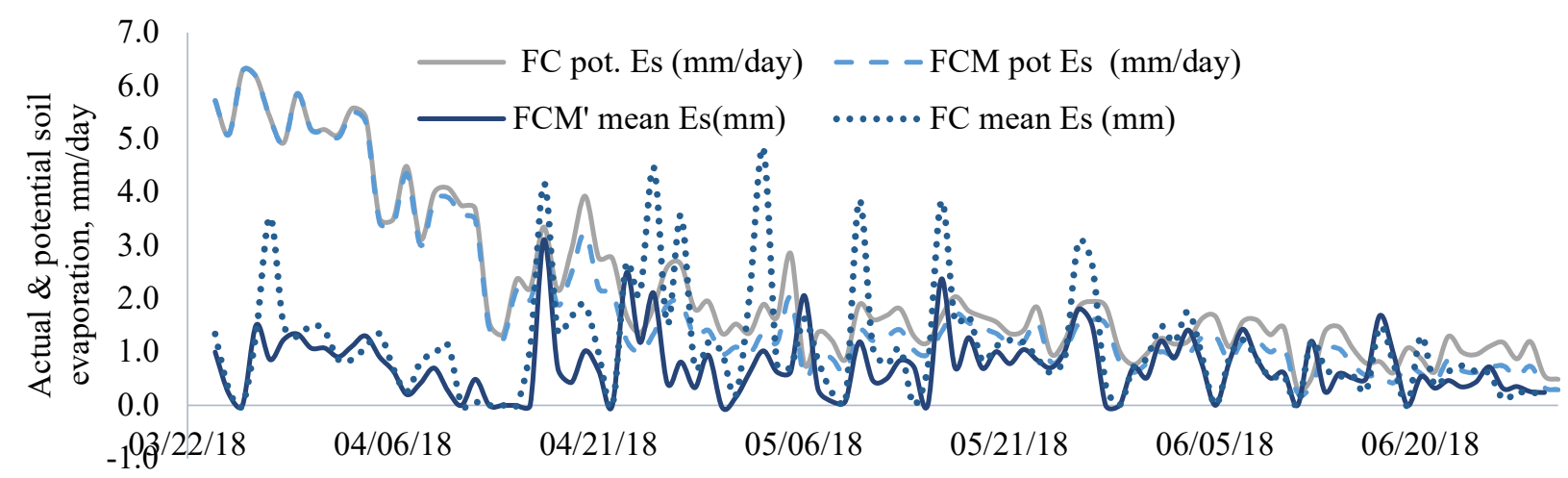

Figure 7. Actual (mean $E_{s}, \mathrm{~mm} /$ day) and potential (pot. $E_{s,}$ mm/day) soil evaporation during rainy days

\subsection{Effects of agricultural practices on soil evaporation}

The treatments had a statistically significant effect on the seasonal $E_{s}(p \leq 0.05)$. The measured $E_{s}$ varied among the treatments and its variation over time depended much on meteorological condition (radiation and rainfall) as they affected both the evaporative power of the atmosphere and the soil moisture content. The daily $\mathrm{E}_{\mathrm{s}}$ level for FCM was the lowest throughout the season as compared to other treatments. Seasonal $\mathrm{E}_{\mathrm{s}}$ was highest in FC plots (a control treatment) $(127 \mathrm{~mm})$, followed by DD $(108 \mathrm{~mm})$ and FCM had $92 \mathrm{~mm}$. The cumulative $\mathrm{E}_{\mathrm{s}}$ in replications followed the same trend (Figure 8). Relative to the FC, DD reduced $\mathrm{E}_{\mathrm{s}}$ by $19 \%$, while mulching (FCM) reduced it by $28 \%$ (Table 2 ). The differences in surface management practices among treatments affected soil evaporation in two ways. First is associated with the surface covers and the second is associated with percolation. For example, the high water loss through Es in bare FC is associated with the exposure of the plots to direct radiations effect from the sun while the low $\mathrm{E}_{\mathrm{s}}$ recorded in the DD especially after rainfall events could be due to redistribution of rainwater into deep depths of the soil profile as also reported by Campbell and Akhtar (1989), thus reducing its escape from near the surface as evaporation. Also, low seasonal $\mathrm{E}_{\mathrm{s}}$ in FCM plots is due to the ability of surface covers to protect the ground from direct heating and reduce water vapour exchange at the soil surface - atmosphere interface.

3.5 Summary on agricultural management practices and their effects

As

We

A 
The

Table 2. Seasonal $\mathrm{E}_{\mathrm{s}}$ and \% reduction by treatments for Masika season of 2018.

\begin{tabular}{cccc}
\hline & \multicolumn{3}{c}{ Treatments } \\
\cline { 2 - 4 } & DD & FC & FCM \\
\hline Seasonal & 108 & 127 & 92 \\
$\mathrm{E}_{\mathrm{s}}$ & 19 & 0 & 35 \\
$\%$ & 15 & 0 & 28 \\
\hline
\end{tabular}

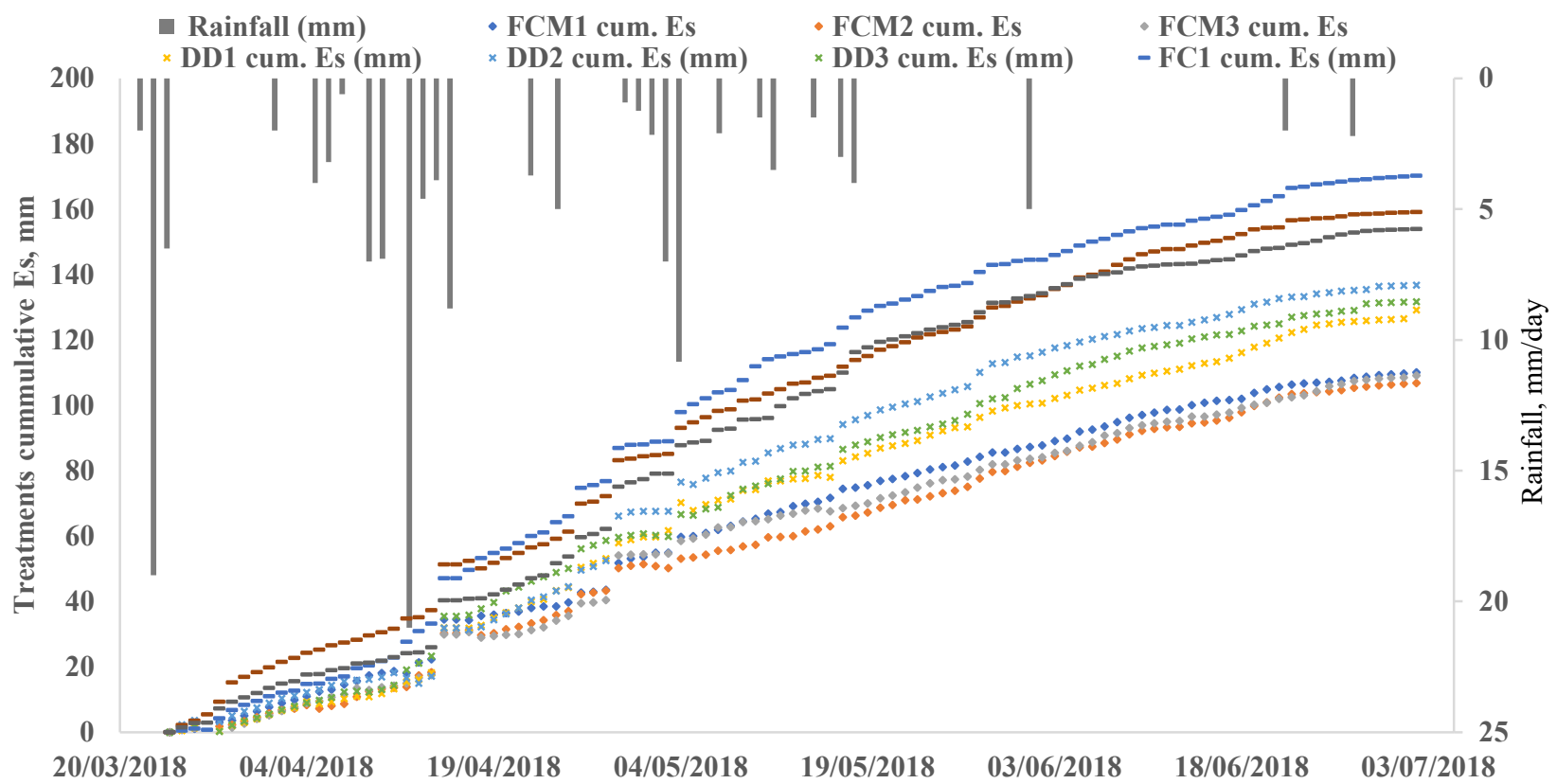

Figure 8. Daily cumulative soil evaporation for FC (dash-lines), DD (x-lines) and FCM (diamondlines) treatments in three replicates with rainfall (bars), for the Masika season, 2018

3.6 Challenges in the method for estimating $E_{s}$

3.6.1 Rainfall records vs weight change in the soil samples

As

The soil evaporation $\mathrm{E}_{\mathrm{s}}$ during a time interval was calculated from the weight loss over the time interval (

$\mathrm{R}$

E

F 
differences between the throughfall entering the soil-ML and the nearby empty ML due to (shortrange) spatial variability in throughfall under a canopy. The first error would lead to a systematic underestimation of $E_{s}$ on rain days, the second error would lead to random errors on $E_{s}$ (both over- and underestimation) on rain days.

In order to assess to what extent evaporation from the empty MLs caused a systematic underestimation of $E_{s}$ on rain days, we grouped the evaporation records (weight losses over 24 hours) in a first group when it rained early in the morning (say shortly after the weight measurement at the start of the 24 hours), and in a second group when it rained late in the evening (after $5 \mathrm{pm}$ ) or at night when there was no or negligible evaporation in the remaining period until the end weight is taken the next morning. The records that were not early or late were grouped in a third group that was not further considered. Evaporation leading to an underestimation is thus a possibility in the first group, but must be negligible in the second group. According to equation 2 the underestimation of throughfall resulted to negative soil evaporation (Figure 9).

In order to assess whether the (short-range) spatial variability in throughfall under a canopy could lead to significant noise on the $\mathrm{E}_{\mathrm{s}}$ data, the variation in measured throughfall between replicate empty MLs placed in the same treatment was quantified. These empty MLs were placed in replicate plots and hence spaced 10-30 meters apart, much more than the 50cm between an empty and a soil-filled ML in our plots. But it is expected that most of the spatial variability in throughfall is situated at short distances due to the canopy architecture of maize (caused by the large leaves and the planting pattern), so any variation in canopy cover at larger distances (10-30 metres), e.g. due to soil variation, will not add much variation to that short-range spatial variability. The coefficient of variation $(\mathrm{CV})$ of the throughfall in replicate plots was less than $7.7 \%$ at the start of the season (when the CC was $<20 \%$ ), it increased to the average of $30.1 \%$ (when the $\mathrm{CC}$ was $\geq 50 \%$ ) and decreased with the $\mathrm{CC}$ decline to $24.1 \%$ (Table 3). This is lower that the CV of throughfall measured in an array of throughfall collectors placed in a $60 * 30 \mathrm{~cm}$ area under a maize canopy in the study by Zheng et al. (2019), who observed that the CV of throughfall ranged between $15 \%$ and over $100 \%$, with the highest CV values observed for high rainfall intensity events. These CV values also include the systematic variation in throughfall that is observed across maize rows, with lowest throughfall at the planting row, and highest in the middle between two planting rows. That systematic variation across the inter-row space was excluded in our study as all MLs were placed at a distance of $35 \mathrm{~cm}$ from the maize rows. This may explain why the CV of throughfall in our experiment was lower than in the study of Zheng et al. (2019). Although there was a variation in throughfall which may have caused the soil containing MLs to record more weights than empty MLs this is not the reason for the few higher soil evaporation than potential evaporation on days with rainfall (Figure 10). The error in the throughfall may have affected the soil 
weights but caused no effect on the $\mathrm{E}_{\mathrm{s}}$ measurements due to the measured constant standard deviation. The few higher $E_{s}$ than $E_{p o t}$ may be due to un noticed reasons which needs more investigations.

Table 3. Average coefficient of variation of the throughfall during three different periods of the season (when the CC was $<20 \%$, at $C C \geq 50 \%$ and after CC decline).

\begin{tabular}{lll} 
Date /Duration & Throughfall CV $(\%)$ & CC $(\%)$ \\
\hline $15 / 3-07 / 4 / 2018$ & 7.7 & $<20$ \\
$8 / 4-25 / 4 / 2018$ & 30.1 & $\geq 50-80$ \\
$3 / 5-30 / 6 / 2018$ & 24.1 & $<80$
\end{tabular}

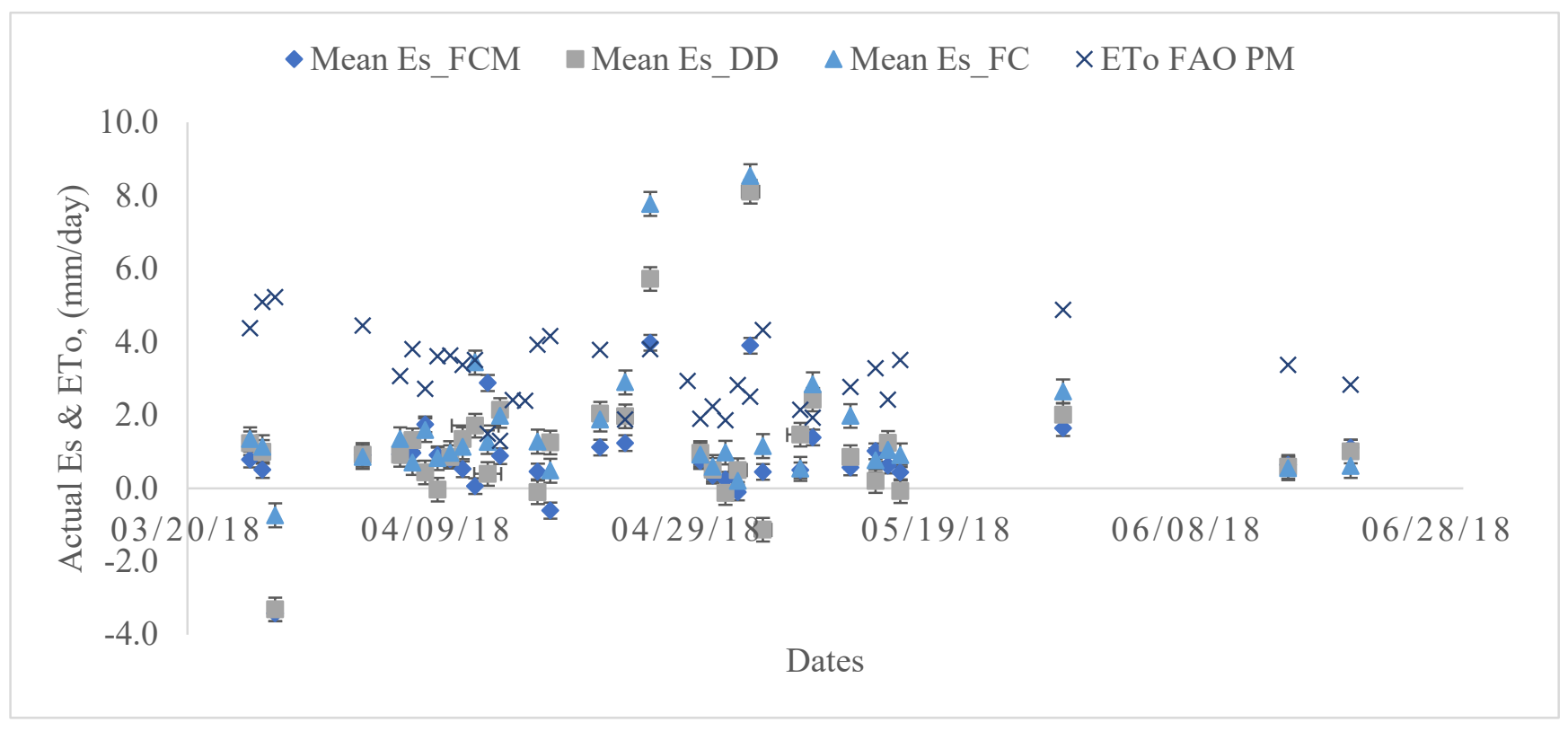

Figure 9. Daily $E_{s}$ and $E T_{o}$, (mm) per treatments (FCM, DD \& FC) as measured by microlysimeter method measured on days with rainfall of the season in Bangalala-Makanya catchment (error bars are $+/$ - standard errors of the means). 


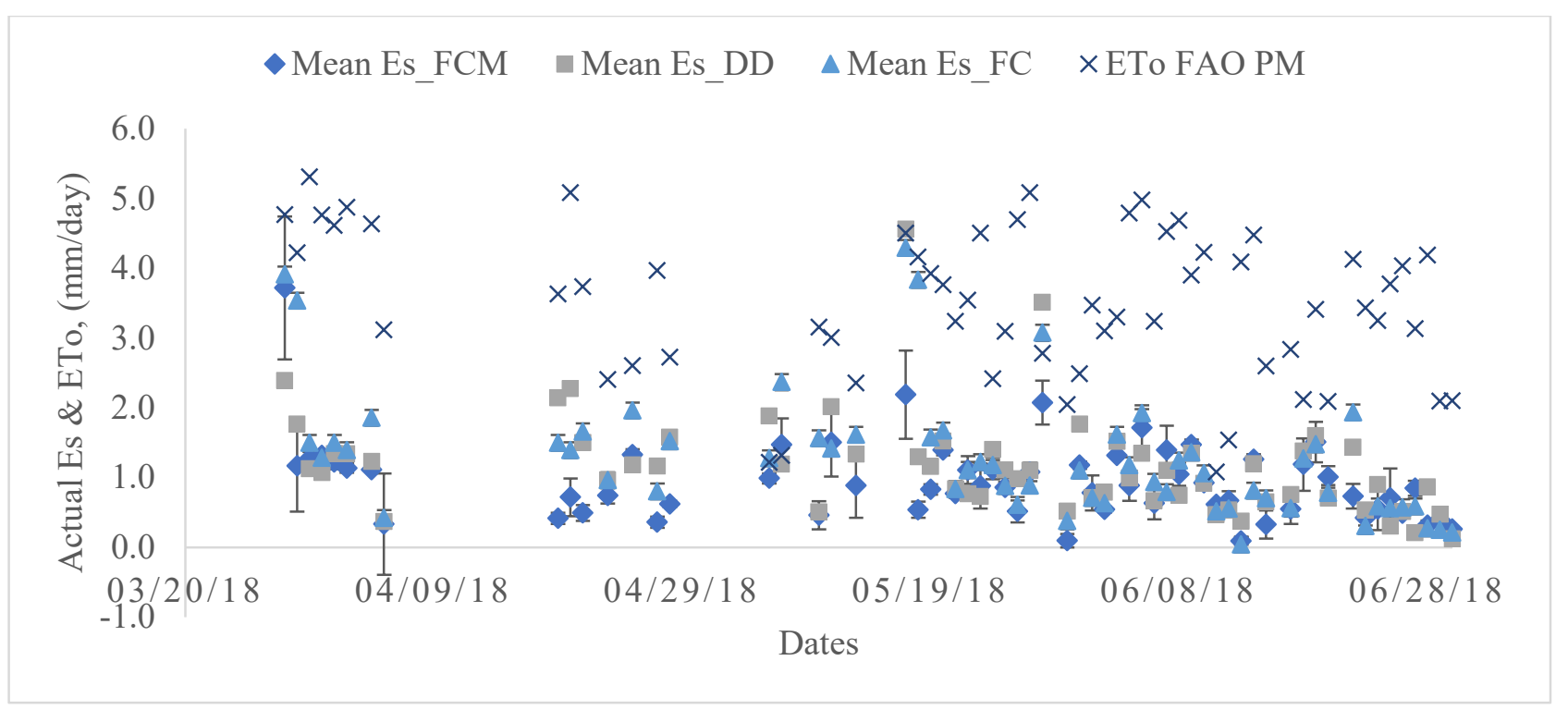

Figure 10. Daily $E_{S}$, and $E T_{o},(\mathrm{~mm})$ per treatments (FCM, DD \& FC) as measured by microlysimeter method measured on days without rainfall of the season in Bangalala-Makanya catchment (error bars are $+/$ - standard errors of the means).

\subsubsection{Managing treatments in ML}

Due to the purpose of the study to evaluate the effect of different agricultural management practices (soil moisture conservation treatments) on water loss from the cropped land, the MLs are used to measure daily $E_{s}$ in each respective treatment. Microlysimeters can be used to quantify the effect of mulching on $E_{s}$, in which the mulch are applied on top of the ML to cover the soil sample in the ML. The DD management practice was reflected into MLs by taking soil samples carefully (without structure alteration) from plots with the same management practice. The same was done for the FC which is the control practice. Because these soil samples in MLs only remained 2-4 days before discard, it was assumed still be a representative of the soil in the ground. The reflection of FCM treatment from the field into the MLs posed no difficulty as compared to DD which was only done in the field and a representative soil sample needed to be taken with much care to control any structure alteration.

\section{Conclusion and recommendations}

We used the microlysimeters to estimate soil evaporation based on direct measurements from a rainfed maize field under different agricultural management practices. The mulching treatment reduced the seasonal soil evaporation by $28 \%$ and the DD treatment reduced it by $19 \%$ in the season in comparison to the control treatment which is the farmers' practice. The DD practice, as hypothesized in section 2.2, seem to have improved the rainfall redistribution into soil layers which is reflected in the SMC results. On the other hand, it may have caused increased water loss during high evaporative 
demand period or dry period. Although the area receives little seasonal rainfall which is less than the crop water requirement (CWR), if FCM treatment is well used can minimize water loss through $\mathrm{E}_{\mathrm{s}}$, hence improve the SMC which covers a part of CWR especially during critical growth period of the crop and sustain it to maturity.

A method worked well on days without rainfall Figure 10, and challenge in the method was observed while estimating $E_{s}$ during rainfall days of the season. During rainfall days, the measured $E_{s}$ values are only correct when the observed throughfall in the empty MLs is exactly the same as the one received in the soil containing MLs.

To improve the method's accuracy during rainfall period we urge that there should be means to measure rainwater throughfall during or immediately after each rain event. This could be done using a small datalogger with a drop counter as described by Mertens et al. (2008). The drop counter could be placed at the bottom of a funnel that collects the throughfall and is placed next to the ML with soil. This would avoid the problem of evaporation from empty MLs which might be taking place between the time of rainfall and after the time of weighing the empty ML the next morning thus causing underestimation of the throughfall into the soil samples. When the throughfall rain is accurately estimated, it will cancel out the weight gained into the soil due to rainfall and there will be no negative values of the $E_{s}$ during rainy period. Also, the study suggests a use of funnels on empty MLs which will allow collection of throughfall and act as covers to minimize water loss from empty MLs. Also, more MLs than the previous number (say 4 MLs both empty and with soil samples) need to be installed into each plot to minimize the random error caused by leave orientations to the throughfall data.

To have more results on reducing water losses while increasing available water for crop growth in this water scarce environment, the study suggests to take an integrated approach. This means, mulches need to be combined with a soil surface management practice which increases plant available water (like DD) by improving redistribution of the rain water into deep depths of the profile. Moreover, more alternative agricultural management practices which may improve water redistribution into layers and plant water availability and thus reducing $E_{s}$ rate while improving the crop yield need to be studied and established.

\section{Acknowledgments}

This work got a financial support from VLIR- UOS (which support partnerships between universities and university colleges in Flanders (Belgium) and the South looking for innovative responses to global and local challenges), through the SMART-ET project. We gratefully acknowledge this assistance.

\section{References}

Allen, R. G., Pereira, L. S., Raes, D., Smith, M., 1998. Crop evapotranspiration -guidelines for 
computing crop water requirements. FAO Irrigation and drainage paper 56. Food and agriculture organization, Rome. http://www.fao.org/docrep/x0490e/x0490e00.htm.

Allen, S. J., 1990. Measurement and estimation of evaporation from soil under sparse barley crops in northern Syria. Agricultural and Forest Meteorology, 49, 291-309. https://doi.org/10.1016/01681923(90)90003-O.

Aydin, M., 2008. A model for evaporation and drainage investigations at ground of ordinary rainfedareas. Ecological Modelling, 217, 148-156. https://doi.org/10.1016/j.ecolmodel.2008.06.015

Balwinder-Singh, Eberbach, P. L., Humphreys, E., Kukal, S. S., 2011. The effect of rice straw mulch on evapotranspiration, transpiration and soil evaporation of irrigated wheat in Punjab, India. Agricultural Water Management, 98, 1847-1855. https://doi.org/10.1016/j.agwat.2011.07.002.

Boast, C. W., Robertson, T. M., 1982. A “Micro-Lysimeter" method for determining evaporation from bare soil: description and laboratory evaluation1. Soil Science Society of America Journal, 46, 689. https://doi.org/10.2136/sssaj1982.03615995004600040005x.

Boesten, J. J. T. I., Stroosnijder, L., 1986. Simple model for daily evaporation from fallow tilled soil under spring conditions in a temperate climate. Netherlands Journal of Agricultural Science, 34, 75-90.

Brutsaert, W., 2014. Daily evaporation from drying soil: Universal parameterization with similarity. Water Resources Research, 50, 5510-5531. https://doi.org/10.1002/2013WR014910.

Campbell, J. A., Akhtar, M. E., 1990. Impact of tillage on soil water regimes in rainfed areas.of Pakstan. In: M.E. Akhtar, M.I. Nizami (Eds.), Soil Physics: Application under Stress Environments. Proceedings of the International Symposium on Applied Soil Physics in Stress Environments, Islamabad, Pakistan, 22-26 January 1989. Pakistan Agricultural Research Council (PARC), Islamabad, pp. 267-275.

Daamen, C. C., Simmonds, L. P., Sivakumar, M. V. K., 1995. The impact of sparse millet crops on evaporation from soil in semi-arid Niger. Agricultural Water Management, 27, 225-242.

Daamen, C. C., Simmonds, L. P., Wallace, J. S., Laryea, K. B., Sivakumar, M. V. K., 1993. Use of microlysimeters to measure evaporation from sandy soils. Agricultural and Forest Meteorology, 65, 159-173. https://doi.org/10.1016/0168-1923(93)90002-Y.

Eberbach, P., Pala, M., 2005. Crop row spacing and its influence on the partitioning of evapotranspiration by winter-grown wheat in Northern Syria. Plant and Soil, 268, 195-208. https://doi.org/10.1007/s11104-004-0271-y.

Enfors, E., Gordon, L., 2007. Analyzing resilience in dryland agro-ecosystems. Land Degradation and Development, 18, 1-21.

Enfors, E., Barron, J., Makurira, H., Rockström, J., Tumbo, S., 2011. Yield and soil system changes 
from conservation tillage in dryland farming: A case study from North Eastern Tanzania. Agricultural Water Management, 98, 1687-1695. https://doi.org/10.1016/j.agwat.2010.02.013

Evett, S. R., Warrick, A. W., Matthias, A. D., 1995. Wall material and capping effects on microlysimeter temperatures and evaporation. Soil Science Society of America Journal, 59, 329.

Gebler, S., Hendricks Franssen, H. J., Pütz, T., Post, H., Schmidt, M., Vereecken, H., 2015. Actual evapotranspiration and precipitation measured by lysimeters: A comparison with eddy covariance and tipping bucket. Hydrology and Earth System Sciences, 19, 2145-2161. https://doi.org/10.5194/hess-19-2145-2015.

Han, J., Lin, J., Dai., Y., 2017. Numerical modeling of soil evaporation process and its stages dividing during a drying cycle. Geofluids 2017.

Harp, D. R., Reda Taha, M. M., Stormont, J. C., Farfan, E., \& Coonrod, J. (2007). An evaporation estimation model using optimized fuzzy learning from example algorithm with an application to the riparian zone of the Middle Rio Grande in New Mexico, U.S.A. Ecological Modelling, 208, 119-128. https://doi.org/10.1016/j.ecolmodel.2007.04.028

Hatfield, J. L., Sauer, T. J., Prueger, J. H., 2001. Managing soils to achieve greater water use efficiency: A review. Agronomy Journal, 93, 271-280.

Howell, D. C., 2008. Mixed Models for repeated measures. https://ncss-wpengine.netdna-ssl.com/wpcontent/themes/ncss/pdf/Procedures/NCSS/Mixed_Models-

Jackson, N. A., Wallace, J. S., 1999. Soil evaporation measurements in an agroforestry system in Kenya. Agricultural and Forest Meteorology, 94, 203-215.

Lascano, R.J., Van Bavel, C. H. M., 1986. Simulation and Measurement of Evaporation from a Bare Soil. Soil Science. Society.of America. Journal, 50, 1127-1132.

Lee, K. J., Carlin, J. B., 2010. Multiple imputation for missing data: Fully conditional specification versus multivariate normal imputation. American journal of epidemiology, 171, 624-632.

Li, S., Li, Y., Lin, H., Feng, H., Dyck, M., 2018. Effects of different mulching technologies on evapotranspiration and summer maize growth. Agricultural Water Management, 201, 309-318.

Li, S. X., Wang, Z. H., Li, S. Q., Gao, Y. J., Tian, X. H., 2013. Effect of plastic sheet mulch, wheat straw mulch, and maize growth on water loss by evaporation in dryland areas of China. Agricultural Water Management, 116, 39-49. https://doi.org/10.1016/j.agwat.2012.10.004.

Makurira, H., Savenije, H. H. G., Uhlenbrook, S., Rockström, J., Senzanje, A., 2011. The effect of system innovations on water productivity in subsistence rainfed agricultural systems in semi-arid Tanzania. Agricultural Water Management, 98,1696-1703.

Makurira, H., 2010. Water productivity in rainfed agriculture. Redrawing the rainbow of water to achieve food security in rainfed smallholder systems. Delft, The Netherlands. 
Makurira, H., Mul, M.L., Vyagusa, N.F., Uhlenbrook, S., Savenije, H.H.G., 2007. Evaluation of community-driven smallholder irrigation in dryland south Pare mountains, Tanzania: A case study of manoo micro dam. Physics and Chemistry of the Earth, 32, 1090-97.

Mason, R., Young, J., 2002. Multivariate statistical process control with industrial applications. Philadelphia: Society for industrial and applied mathematics

Mastrorilli, M., Katerji, N., Rana, G., Nouna, B. B., 1998. Daily actual evapotranspiration measured with TDR techinique in Mediterranean conditions. Agricultural and Forest Meteorology, 90, 8189.

Matthias, A. D., Salehi, R., Warrick, A. W., 1986. Bare soil evaporation near a surface point-source emitter. Agricultural Water Management, 11, 257-277.

Mertens, J., Diels, J., Vanderborght, J. and Feyen, J., 2008. Design and testing of a drop counter for use in vadose zone water samplers. Vadoze Zone Journal, 7, 434-438.

Mul, M L, Savenije, H. H. G., Uhlenbrook, S., 2009. Understanding key hydrological processes in a meso-scale semi-arid catchment in Tanzania by using a multi-method approach. Assembly 11: 7336.

Mul, M. L., 2009. Understanding Hydrological Processes in an Ungauged Catchment in sub-Saharan Africa. Delft University of Technology, The Netherlands

Mutiro, J., Makurira, H., Senzanje, A., Mul, M. L., 2006. Water productivity analysis for smallholder rainfed systems: A case study of Makanya catchment, Tanzania. Physics and Chemistry of the Earth, 31, 901-909. https://doi.org/10.1016/j.pce.2006.08.019.

Nyenzi, B. S., Kiangi, P. M. R., Rao, N. N. P., 1981. Evaporation values in East Africa. Archives for Meteorology, Geophysics, and Bioclimatology, 29, 37-55. https://doi.org/10.1007/BF02278189

Or, D., Lehmann, P., Shahraeeni, E., Shokri, N., 2013. Advances in soil evaporation physics-A review. Vadose Zone Journal, 12, 1-16. https://doi.org/10.1016/0022-2313(76)90010-7.

Pachpute, J. S., Tumbo, S. D., Sally, H., Mul, M. L., 2009. Sustainability of rainwater harvesting systems in rural catchment of Sub-Saharan Africa. Water Resources Management, 23, 2815 2839. https://doi.org/10.1007/s11269-009-9411-8.

Patrignani, A., Tyson, E. O., 2015. Canopeo: A powerful new tool for measuring fractional green canopy cover. Agronomy Journal, 107, 2312-20.

Plauborg, F., 1995. Evaporation from bare soil in a temperate humid climate-measurement using micro-lysimeters and time domain reflectometry. Agricultural and Forest Meteorology, 76, 117. https://doi.org/10.1016/0168-1923(94)02215-6.

Ritchie, J., 1972. Model for predicting evaporation from a row crop with incomplete cover, Water Resources Research, 8, 1204-121. DOI: 10.1029/WR008i005p01204. 
Rockström, J., Barron, J., Fox, P., 2003. Water productivity in rain-fed agriculture: Challenges and opportunities for smallholder farmers in drought-prone tropical agroecosystems. Water productivity in agriculture: Limits and Opportunities for Improvement, pp.145-162.

Schwartz, R. C., Baumhardt, R. L., Evett, S. R., 2010. Tillage effects on soil water redistribution and bare soil evaporation throughout a season. Soil and Tillage Research, 110, 221-229.

Shawcroft, R. W., Gardner, H. R., 1983. Direct evaporation from soil under a row crop canopy. Agricultural Meteorology, 28, 229-238. https://doi.org/10.1016/0002-1571(83)90028-6.

Sillon, J. F., Richard, G., Cousin, I., 2003. Tillage and traffic effects on soil hydraulic properties and evaporation. Geoderma, 116, 29-46. https://doi.org/10.1016/S0016-7061(03)00092-2

Schneider, F., Don, A., Hennings, I., Schmittmann, O., Seidel, S. J., 2017. The effect of deep tillage on crop yield - What do we really know? Soil and Tillage Research, 174, 193-204.

Sutanto, S. J., Wenninger, J., Coenders-Gerrits, A. M. J., Uhlenbrook, S., 2012. Partitioning of evaporation into transpiration, soil evaporation and interception: A comparison between isotope measurements and a Hydrus-1D model. Hydrology and Earth System Sciences, 16, 2605-2616.

UN Population Division, 2012. World Population Prospects: the 2010 Revision. Waste Management Research, 27, 800-812.

Van den Putte, A., Govers, G., Diels, J., Gillijns, K., Demuzere, M., 2010. Assessing the effect of soil tillage on crop growth: A meta-regression analysis on European crop yields under conservation agriculture. European Journal of Agronomy, 33, 231-241.

Walker, G.,1983. Measurement of evaporation from soil beneath crop canopies. Canadian Journal of Soil Science, 63, 137-141.

Wallace, J. S., 1995. Calculating evaporation: resistance to factors. Agricultural and Forest Meteorology, 73, 353-366. https://doi.org/10.1016/0168-1923(94)05084-J

World Health Organization, 2000. World population growth. Beyond economic growth, 1-6.

World Bank, 2002. World development report 2002. World development.

Wythers, K. R., Lauenroth, W. K., Paruelo, J. M., 1999. Bare-soil evaporation under semiarid field conditions. Soil Science Society of America Journal, 63, 1341.

Zhang, S., Li, P., Yang, X., Wang, Z., \& Chen, X. (2011). Effects of tillage and plastic mulch on soil water, growth and yield of spring-sown maize. Soil and Tillage Research, 112(1), 92-97.

Zheng, J., Fan, J., Zhang, F., Yan, S., Wu, Y., Lu, J., Guo, J., Cheng, M., Pei, Y., 2019. Throughfall and stemflow heterogeneity under the maize canopy and its effect on soil water distribution at the row scale. Science of the Total Environment, 660, 1367-1382.

Zribi, W., Aragüés, R., Medina, E., Faci, J. M., 2015. Efficiency of inorganic and organic mulching materials for soil evaporation control. Soil and Tillage Research, 148, 40-45. 